E International

\title{
Public Acceptability of Sustainable Transport Measures
}

A Review of the Literature

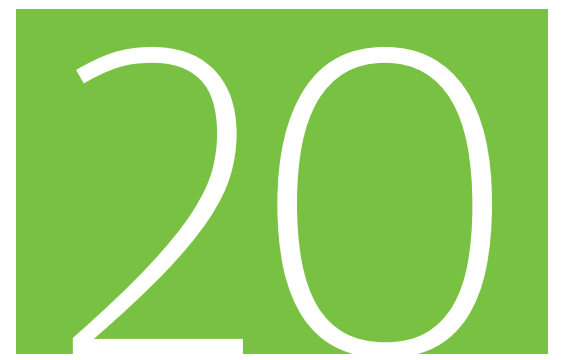

Discussion Paper $2011 \bullet 20$

Alison PRIDMORE

Apollonia MIOLA

European Commission -

Joint Research Centre 
This document was produced as background for the 2011 International Transport Forum, on 25-27 May in Leipzig, Germany, on Transport for Society. The views expressed in this document do not necessarily reflect those of the member countries of the International Transport Forum.

Further information about the International Transport Forum is available at www.internationaltransportforum.org 


\title{
Public Acceptability of Sustainable Transport Measures: \\ A Review of the Literature
}

\author{
ies \\ Discussion Paper No. 2011-20

\begin{abstract}
Alison PRIDMORE
Apollonia MIOLA

European Commission - Joint Research Centre

Institute for Environment and Sustainability
\end{abstract}

May 2011 


\section{INTERNATIONAL TRANSPORT FORUM}

The International Transport Forum at the OECD is an intergovernmental organisation with 52 member countries. It acts as a strategic think tank with the objective of helping shape the transport policy agenda on a global level and ensuring that it contributes to economic growth, environmental protection, social inclusion and the preservation of human life and well-being. The International Transport Forum organizes an annual summit of Ministers along with leading representatives from industry, civil society and academia.

The International Transport Forum was created under a Declaration issued by the Council of Ministers of the ECMT (European Conference of Ministers of Transport) at its Ministerial Session in May 2006 under the legal authority of the Protocol of the ECMT, signed in Brussels on 17 October 1953, and legal instruments of the OECD.

The Members of the Forum are: Albania, Armenia, Australia, Austria, Azerbaijan, Belarus, Belgium, Bosnia-Herzegovina, Bulgaria, Canada, Croatia, the Czech Republic, Denmark, Estonia, Finland, France, FYROM, Georgia, Germany, Greece, Hungary, Iceland, India, Ireland, Italy, Japan, Korea, Latvia, Liechtenstein, Lithuania, Luxembourg, Malta, Mexico, Moldova, Montenegro, Netherlands, New Zealand, Norway, Poland, Portugal, Romania, Russia, Serbia, Slovakia, Slovenia, Spain, Sweden, Switzerland, Turkey, Ukraine, the United Kingdom and the United States.

The International Transport Forum's Research Centre gathers statistics and conducts cooperative research programmes addressing all modes of transport. Its findings are widely disseminated and support policymaking in Member countries as well as contributing to the annual summit.

\section{DISCUSSION PAPERS}

The International Transport Forum's Discussion Paper Series makes economic research, commissioned or carried out at its Research Centre, available to researchers and practitioners. The aim is to contribute to the understanding of the transport sector and to provide inputs to transport policy design. The Discussion Papers are not edited by the International Transport Forum and they reflect the author's opinions alone.

The Discussion Papers can be downloaded from: www.internationaltransportforum.org/itrc/DiscussionPapers/jtrcpapers.html

The International Transport Forum's website is at: www.internationaltransportforum.org or further information on the Discussion Papers and other JTRC activities, please email: itf.contact@oecd.org 


\section{TABLE OF CONTENTS}

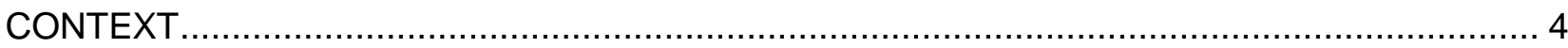

1. IDENTIFICATION OF TRANSPORT'S EFFECTS AND MITIGATION MEASURES ................ 5

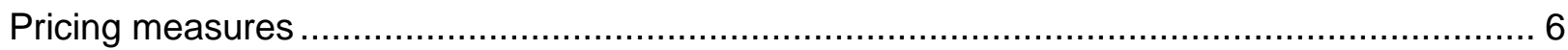

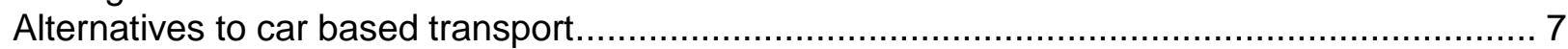

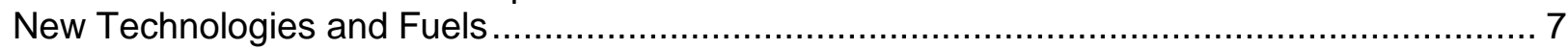

2. KEY THEMES FOR PUBLIC ACCEPTABILITY OF THE DIFFERENT MEASURES .............. 8

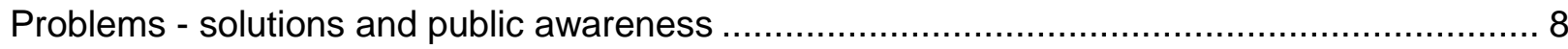

Wider benefits and impact........................................................................................... 11

The need for trust and alignment with values and norms …......................................... 12

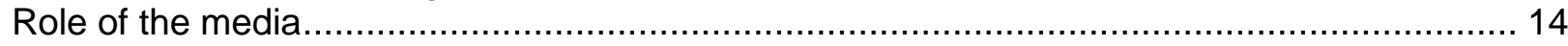

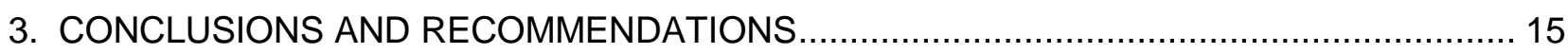

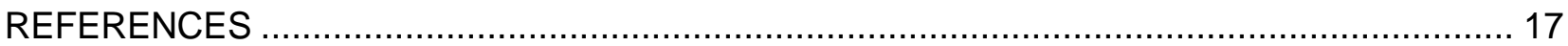




\section{CONTEXT}

Increasingly, the debate on transport policy involves the challenge of sustainable development. The concept of sustainable transport is derived from the general term of sustainable development. Sustainable transportation can be considered by examining the sustainability of the transport system itself, in view of its positive and negative external effects on: the environment; public health; safety and security; land use; congestion; economic growth; and social inclusion (OECD, 2000).

While traditional transport problems may be solved within the transport sector (i.e. satisfying basic needs of the movement of people and goods by the provision of large scale transport networks), solutions to sustainability problems call for an integrated approach. This approach should take into account the acceptability of sustainable transport policies that may conflict with individual short-term interests, especially when individual users are asked to significantly adapt their lifestyles and transport behaviour with impacts on their perceived quality of life (Miola, 2008).

Political efforts towards the sustainability of the transport sector are in place (e.g. EC, 2011). These are, however, in the context of trends which could not be called sustainable. Currently, the main trends are related to increasing mobility demand, more cars driving more and longer distances; cheaper and cheaper travel prices allowing easy access to faraway places; and infrastructures and habits adjusted to road transport (EEA, 2009). As noted above public acceptability of the measures to address these trends and achieve sustainable transport is required.

This paper, which is a literature review on public acceptability of transport measures, will identify some of the difficulties faced in achieving this acceptability. Its focus, more importantly, will be on identifying positive ways forward.

In terms of the review the emphasis was on literature which considered public acceptability of (sustainable) transport measures rather than the broader literature on sustainable transport per se. The aim of the review is, purposefully, a synthesis of the literature relevant to the guiding questions set out below, rather than an in-depth systematic review.

1. Is there a focus - in the literature on public acceptability - on certain transport effects? If so, what are these effects? And what are the transport measures used to mitigate them?

The review found a focus on negative effects. With the measures used to address them including: pricing, alternatives to car use and new technologies and fuels. These are used to frame the latter stage of this section of the report.

2. What are the key themes in terms of achieving the social acceptability of these measures? What can we learn from this?

In considering (2) a number of themes emerged and are used as a framework in the relevant section. These included:

- Is there a problem? Will the solution(s) work? At which stage in the process is the public being asked? 
- Where does the money go? Are there wider benefits and impacts?

- Is there trust in those implementing the scheme? And trust that others will also act? How does it align with individual and group norms and values? Is it fair?

- Does the media influence opinion? Does the public influence the media?

The approach is innovative in that it set out to compare and draw findings from a range of transport literature considering behavioural change mechanisms such as pricing as well as technological change. While caution is of course required, like is not necessarily being compared with like, this approach brought a useful and different viewpoint to the understanding of the key themes as they relate to acceptability and change.

The structure of the report is as follows:

1. Identification of transport's effects and mitigation measures

2. Key themes for the public acceptability of the different measures

3. Conclusions and recommendations

\section{IDENTIFICATION OF TRANSPORT'S EFFECTS AND MITIGATION MEASURES}

The following section first details the effects of the transport system in a broad sustainable development context covering social, environmental and economic aspects. It then turns to the literature on public acceptability (of transport measures) to discern whether there is a focus on certain effects. Mitigation measures used are then considered in detail.

The main reason for the transport system to exist - to provide access to: resources, services and markets (central components for the generation of welfare), emphasizes the social dimension of sustainability of transport. In this framework, the accessibility concept is central. (Farrington, 2007).

The environmental dimension of a sustainable transport system highlights the stress on the natural environment which the transport activity causes (air quality pollution, climate change, noise pollution, landscape fragmentation, loss and disturbance of habitats and species due to provisions and utilization of transport infrastructures) (OECD, 2000).

The notion of economically sustainable transport relies on full cost accounting and full costpricing systems reflecting economic factors which originate from transport activity inhibiting sustainable development (namely, externalities; spillover effects and non-priced inter-sectorial linkages; public goods; uncompetitive markets; risk and uncertainty, irreversibility and policy failures) (Panaytou, 1992). Other definitions of economically sustainable transport state that transport must be "cost-effective and responsive to continuously changing demands in a way that commercial and free market can operate without significant adverse externalities and distributional consequences" (UN, 2001).

To achieve sustainable transport a wide range of positive and negative effects are identified, as detailed above. The focus of the literature review for this study was on the public acceptability of transport measures. Here, the review suggested an emphasis on measures which helped mitigate transport's negative effects. Negative effects identified include its contribution to: climate change (e.g. Bristow et al, 2010, Schuitema et al, 2010, Eriksson et al, 
2008, Ryley et al, 2009), congestion (e.g. Gaunt et al, 2007, Garling and Schuitema, 2007, Gehlert et al, 2011) ${ }^{1}$, local air pollution and noise (e.g. Eriksson et al, 2008) and traffic accident risk (e.g. Garling and Schuitema, 2007). Note that the studies often identified more than one negative effect. Research on public attitudes to transport (Goodwin and Lyons, 2010) corresponds with this. The research identifies congestion as a key issue (in a majority context, but less so at the individual and family level) and behaviour change to address environmental issues.

Three key themes as they relate to the measures to address these negative effects were identified. These are: (i) pricing measures, most typically road pricing; (ii) alternatives to car based transport (here investment in public transport is a key theme); and (iii) new technologies and fuels.

The focus in the literature is on car based private transport reflecting its historic contribution as a travel mode and the associated sustainability impacts. This report therefore reflects this focus.

However, it is essential to also note the recent and continuing growth in the aviation and shipping sectors (e.g. Miola et al, 2010). We anticipate, therefore, that these sectors will become key areas of future research on public acceptability. For aviation, this includes research which considers modal shift to lower carbon modes; for business travel the potential for teleconferencing; and changes in consumption patterns to reduce holiday demand and requirements for air freight. For shipping, the focus will be on freight. The use of new technologies and fuels is relevant to both modes. Understanding attitudes to and acceptability of measures to facilitate these changes for example pricing mechanisms or broader societal changes will be key.

The themes introduced earlier - pricing measures; alternatives to car based transport and the use of new technologies and fuels are considered in turn below. The emphasis here is on drawing out key overarching ideas, rather than an in-depth analysis.

It is important to note that in general terms several policy measures should be combined to address transport's impacts when designing policies for sustainability. According to Himanen et al (2005), the debate on weak and strong sustainability can be translated into the design of sustainable transport policies. On the one hand, application of a weak sustainability vision is a gradual policy characterized by marginal and indirect interventions to make transport ecoefficient. On the other hand, a radical policy, which puts caps on transport volumes and speeds, can be considered the policy choice connected to a strong sustainability vision (Miola, 2007).

\section{Pricing measures}

In order to reduce transport demand and/or ensure that the demand is 'optimal' pricing measures can be used. Since pricing measures typically involve a charge to access a 'good' which historically the public has used for free, public acceptability is a key theme in the literature. This literature can be, approximately, split into three categories: city based charging; road pricing measures (more broadly) and taxes or quota based mechanisms ${ }^{2}$.

1. Delays and unreliable journey times have financial impacts.

2. Note that parking charges are also considered, but to a lesser extent. 
City based (or urban) charging schemes, are a focus of the literature on public acceptability (e.g. Gaunt et al, 2007, Winslott-Hiselius et al, 2009, Elliason, 2010, Gehlert et al, 2011, Kottenhof and Brundnell Freij, 2009, Schade and Schlag, 2003) no doubt reflecting the availability of real-life data and schemes. The main benefit identified is congestion reduction. Though, other benefits, for example improvements in air quality are recognised.

Road pricing measures, more broadly, are also evaluated. This evaluation can identify potential impacts of measures and mechanisms to increase acceptability (e.g. De Groot and Steg, 2006, Schuitema and Steg, 2008, Schuitema et al, 2010). These measures are introduced to address sustainability concerns more broadly.

Research on public acceptability of transport fuel taxes or quota based mechanisms is currently more limited. The environmental benefits of the taxes, in particular carbon reduction, is a key sustainability issue identified (e.g. Bristow et al, 2010). Revenue raising (economic) aspects are also recognised (e.g. with regard to the Fuel Duty Escalator in the UK, Marsden, 2002).

\section{Alternatives to car based transport}

Alternatives to car based transport are considered in the literature, often in the context of increasing the acceptability of pricing measures (for example Kottenhof and Brundnell Freij, 2009; Eriksson et al, 2008). This can include practical considerations for example increased public transport levels can ensure that modal shift from car will be catered for. As such they contribute to the social acceptability of pricing measures. The public perception of non-coercive or 'pull' measures are that they are fairer, more effective and correspondingly more acceptable in comparison with 'push' measures such as pricing (e.g. Eriksson el al, 2008). This acceptance, understandably, means less evaluation within the 'public acceptability' literature.

Measures to reduce distance travelled, for example through telecommuting or spatial planning, are identified as helping to achieve carbon reduction in the transport sector. In terms of attitudes to and acceptability of, the focus is on the latter. Relatively little consideration is given to the acceptability of changes in spatial planning (increases in urban density) to facilitate modal shift to the lower carbon modes of walk, cycle and public transport.

\section{New Technologies and Fuels}

A number of different technologies and fuels are envisioned for personal road transport. Future technologies include plug-in hybrids, electric and fuel cell vehicles, while alternative fuels include electricity, hydrogen and biofuels. The focus in the public acceptability literature tends to be on technologies achievable in the longer term for example hydrogen fuel cell vehicles (e.g. O'Garra et al, 2005, O'Garra et al, 2007, Yetano Roche et al, 2010, Thesen and Langhelle, 2008) This could however, also reflect historic expectations for different technologies e.g. hydrogen was an area of much technical interest in the early 2000's, and this could in turn could have influenced the public acceptability research. Hydrogen and fuel cell vehicles, given the substantive changes required could be viewed as a radical technology and therefore potentially identified as an area where in-depth research on acceptability is required.

Electric vehicles are increasingly anticipated to play an important role in achieving carbon reduction. Research focusing on acceptability is currently limited. Reflecting this Morton et al (2011) provides a valuable framing exercise examining the literature pertinent to whether consumers will get 'charged up' about electric vehicles. Barriers and opportunities are identified at the individual, meso and macro level and are explored in the following section where key themes in terms of public acceptability are considered. 
Biofuels are thought provoking because they have already been introduced, at low levels, within the current transport fuel mix (Atanasiu, 2010). At these low levels, changes in the vehicle type are not required. Public acceptability of the potential sustainability impacts of these biofuels (positive and negative) would also perhaps need to be framed in the context of acceptance of oil (and its associated impacts).

In terms of the sustainability benefits of the new technologies and fuels there is an emphasis on environmental benefits, in particular the potential for carbon reduction and energy security. Social and economic benefits are, however, also identified. For example Savvanidou et al (2010) which looks at the acceptability of biofuels in Northern Greece suggests that linking biofuel with farm employment opportunities could help increase acceptability. In terms of social aspects, the symbolism of lower carbon, more energy efficient, vehicles is identified as being wider than existing ideas (which include environmental preferences, reducing dependence on oil, and techno knowledge). More broadly, the concepts are linked to ethics, concern for others and an aim for national independence (as related to oil) (Heffner et al, 2007).

In summary, there is a range of literature on acceptability of measures to improve the sustainability of transport. The focus in this literature is on addressing transport's negative effects. In terms of measures one could suggest that historically there is a focus on pricing measures with the negative effect addressed typically being congestion. Climate change is increasingly identified as a key negative effect. To help address this significant levels of vehicle technology change and other behavioural mechanisms are required. To facilitate this improved understanding of public attitudes to and acceptability of measures is key.

\section{KEY THEMES FOR PUBLIC ACCEPTABILITY OF THE DIFFERENT MEASURES}

In terms of achieving public acceptability of the different measures a number of key themes were identified in the literature. These were drawn, where appropriate, from all of the measures identified: pricing measures, alternatives to car based transport, and the introduction of new technologies and fuels. This broad approach enables the key barriers and opportunities for change to be identified. The themes are:

- Is there a problem? Will the solution(s) work? At which stage in the process is the public being asked?

- Where does the money go? Are there wider benefits and impacts?

- Is there trust in those implementing the scheme? And trust that others will also act? How does it align with individual and group norms and values? Is it fair?

- Does the media influence opinion? Does the public influence the media?

These themes are discussed in turn below, with positive ways forward identified.

\section{Problems - solutions and public awareness}

Policies are more acceptable if the public is aware of the negative impacts associated with car use and they understand the need for measures to address these impacts. For example, acceptability of transport pricing is dependent on problem awareness (e.g. Schade and Schlag, 2000, Bird and Morris, 2006, Oehry, 2010), and the recognition of the need for a far-reaching solution (e.g. Bird and Morris, 2006). 
The measures need to be seen as being effective - the public need to believe that it will work. This is a common theme with regard to pricing measures. For example, Schuitema et al, (2010) suggest that public perceptions that pricing measures are ineffective at reducing congestion and environmental problems are responsible for the lack of acceptability, rather than the negative effects of the measures on personal car use. While Gaunt et al, (2007) (in a survey of Edinburgh residents post pricing referendum) suggested that the public agreed that congestion was a key problem, but they did not believe that the proposed scheme was an effective means of mitigating it. Consulting and engaging with members of the public at the scheme design stage can help ensure understanding of the scheme and its effectiveness. Interestingly, Musselwhite and Lyons, (2009) identify the potential for a segmentation or targeting approach recognising that some groups are more amenable to the concept of road pricing than others.

This is relevant for technology and fuel solutions too, car owners are more willing to pay extra for biofuels if they believe that biofuels are an effective solution to climate change (Savvanidou et al, 2010).

In order for the public to understand that the measures are effective they need to be able to understand it. Correspondingly, the need to avoid complexity is identified in a number of studies. Gaunt et al, (2007) which examined the Edinburgh congestion charging scheme suggest the scheme would have had more success if it had been simpler, more easily communicated, with more attention spent on influencing residents of its benefits. They argue that 'it was clear that that it was too complicated to be understood, never mind supported, by a majority of the public'. In comparison, the London Congestion Charge was introduced at $£ 5$ per day, for all vehicles and affected the 'circle' that is inner London. The scheme was not economically optimal (in academic terms) but was and is easily understandable. Involving and consulting the public at the design stage of any scheme proposal can help determine level of understanding and whether and how this needs to be addressed. Care is however also required, Eliasson (2010) warns of the problems of over-simplification suggesting that making the scheme too simple could diminish its congestion reduction capability and if this over-simplification occurs at the early design stage it could be difficult to rectify later on.

The need to understand was identified for technologies and fuels too. Prior knowledge of hydrogen was identified as the main determinant of support for the introduction of $\mathrm{H} 2$ vehicles in a London based study (O'Garra et al, 2005). While, Morton et al (2011) suggest that the unfamiliar characteristics of electric cars may make them more difficult to implement. One difficulty in promoting the benefits of new, more fuel efficient, vehicle technologies is that public understanding of vehicle efficiency is limited. It is suggested that consumers use 'simple rules of thumb' to assess vehicle efficiency (Anable et al, 2008). Means to address this include use of fuel cost information on a per model basis, and the potential for car manufacturers to position themselves as providers of fuel efficient vehicles (Anable et al, 2008).

Not surprisingly, therefore, trialability and observability are important in the take up of new technologies (Rogers, 2003). Research in the US on hybrid vehicles, suggests that the degree of market penetration increases consumer confidence (e.g. Mau et al, 2008 and Axsen et al, 2009) and that the penetration rate affects new purchases (Heutel and Muehlegger, 2010). The term often used here is a 'neighbourhood effect'.

Trials can also play an important role in ensuring that the public can see that the pricing measures work and brings benefits. With Winslott-Hiselius et al, (2009) suggesting that trials could be an important and influential tool to assist with implementing more challenging policy measures such as congestion charging. 
That the acceptability of a scheme changes over time is related to this. Goodwin, (2006) through an evaluation of a number of road pricing schemes uses a diagram to encapsulate how public acceptability of road pricing alters over time ${ }^{3}$. See Figure 1 below.

Figure 1. Goodwin's cycle of public acceptability

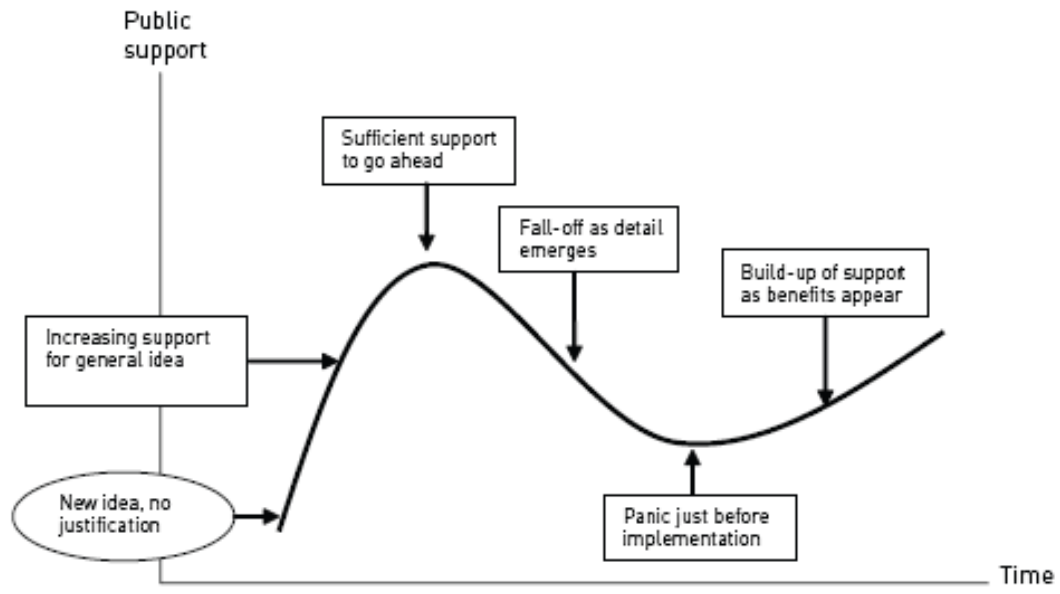

Source: Goodwin, 2006 (note diagram is the one used in Bird and Morris)

Table 1. Public attitude to congestion charging

\begin{tabular}{|c|c|c|}
\hline Scheme & Against/Negative & For/Positive \\
\hline Stockholm Congestion Charging & $\begin{array}{l}2001-51 \% \\
2006-46 \%\end{array}$ & $\begin{array}{r}2001-38 \% \\
2006-52 \%\end{array}$ \\
\hline London congestion charging & $\begin{array}{r}2002-40 \% \\
2003-24-28 \%\end{array}$ & $\begin{array}{r}2002-40 \% \\
2003-48-57 \%\end{array}$ \\
\hline \multicolumn{3}{|l|}{ Urban road pricing in Norway } \\
\hline Bergen & $\begin{array}{r}\text { Before }-81 \% \\
\text { After }-42 \%\end{array}$ & $\begin{array}{r}\text { Before }-19 \% \\
\text { After }-58 \%\end{array}$ \\
\hline Oslo & $\begin{array}{r}\text { Before }-70 \% \\
\text { After }-59 \%\end{array}$ & $\begin{array}{r}\text { Before }-30 \% \\
\text { After }-41 \%\end{array}$ \\
\hline Trondheim & $\begin{array}{r}\text { Before }-91 \% \\
\text { After }-53 \%\end{array}$ & $\begin{array}{r}\text { Before }-9 \% \\
\text { After }-47 \%\end{array}$ \\
\hline
\end{tabular}

Sources: Norway - Tretvik, 2003 London - Transport for London, 2004Stockholm - Poll for Dagens Nyheter newspaper (in Vagverket 2002) and Transport Times 2006, in Morris and Bird 2006.

There are three stages to this acceptability. First is recognition of a problem and increasing public support for the proposed mitigation measure. Second is the reduction in this support as detailed information about the scheme is forthcoming. Finally, once people have experience of a scheme - after a successful introduction - acceptability increases again. In a highly relevant paper Goodwin and Lyons (2009) identify the need for data and analysis at the individual level (rather than aggregate) to understand these types of changes in attitudes to transport measures more broadly and over longer time periods.

The three stages of road pricing acceptability are shown in Table 1, which illustrates the differences in attitudes to congestion schemes before and after introduction. Bird and Morris (2006) which complement Goodwin's work with looking at trends in attitudes in-depth concur with Goodwin - support for road pricing decreases as the time of its introduction nears.

Note that in Oslo, it is suggested in Larsen, (1995), that the smaller opinion shift could be due to the toll cordon being in operation 24 hours a day.

3. Note: Goodwin caveats the origin of the diagram (no source is found) suggesting it could be a collective product of the work of the transport profession. 
Eliasson (2010) discusses the cycle of acceptability in the context of the Stockholm Congestion Charging scheme. Four reasons for the increase in acceptability are identified. First is that the positive effects are greater than anticipated. Second is that the changes associated with the introduction of the scheme for example travel costs or patterns are less than the public expect or indeed fear. The third is summarised as 'accept the inevitable' suggesting that once changes are in place the public are more accepting - with the energy involved in opposing what is already introduced considered to be not well spent. Finally, is that reluctance to the pricing of a previously 'free' good diminishes. Other studies identify further reasons with Winslott-Hiselius et al, (2009) suggesting that the Stockholm trial allowed people to understand its effects in terms of personal interests rather than simply understanding the effects.

In working through this cycle of acceptability, strong leadership is often identified as playing an important role. For example in London, the leadership from the Mayor - Ken Livingstone was seen as integral to the successful introduction of the scheme. On the other hand, in Edinburgh, the absence of a clear political leader has been identified as a contributing factor to its failure. Strong political leadership is not, however, a pre-requisite for action, since in Stockholm political leadership was split. The congestion charging trial was a result of a compromise between the Green party and the Social democrats (Eliasson, 2008). Support from the Green party was dependent on the introduction of the trial and necessary for the Social democrats to remain in power. Furthermore, the introduction of the trial was inconsistent with the position of the leader of Stockholm Social democrats who had promised that there would be no congestion charging in Stockholm in the next election period (Eliasson, 2008) ${ }^{4}$.

Linked to political decisions Eliasson (2010) identifies the importance of the timing of elections and referendums within the acceptability cycle. In London, the Mayoral election (with congestion charging part of Ken Livingstone's manifesto) was held ahead of the development of comprehensive details of the scheme. In Stockholm the referendum was held after the system had been in place for more than six months. While, in Edinburgh and Manchester - where the introduction was not successful - referendums were held after the development of the proposals i.e. at the exact time where a fall off in support would be expected to occur.

In summary, members of the public need to understand that there is a need for change and be convinced that the measure selected will be efficient. Means of helping achieve this is identified in the literature include: understandable schemes, and clear, accessible information and education provision. Here 'real-life' examples in the form of trials and neighbourhood effects could play an important role. Finally, it is suggested that when introducing schemes acceptance will decrease just before implementation. Strong leadership, political will and careful timings can therefore help to see the measures through.

\section{Wider benefits and impact}

Whether, how and where revenue is raised and spent has a key impact on the acceptability of pricing and tax schemes. Where the aim is to replace one tax with another - more efficient or equally preferable one - revenue neutrality is relatively (though not entirely) straightforward (OECD/ITF, 2010). Where the new tax means the internalisation of an external cost, e.g.

4. Eliason, 2008 provides useful information on what happened post referendum. The referendum for the trial took place at the same time as the general election. The results from the referendum were mixed with clear support from the City of Stockholm, but not the neighbouring municipalities who had held their own referendums (which was around 50\%). However, neighbouring municipalities who did not hold referendums were (according to polls) more likely to support the introduction of the trial, and argued that it was up to the City of Stockholm to decide. The new government, which was Liberal-Conservative, reintroduced the charges as part of a more comprehensive transport package. 
congestion, revenue is typically raised (OECD/ITF, 2010). Here, an overarching message is that it should not disappear into a general public spending pot or appear to be 'just another tax' (e.g. Oehry, 2010). Acceptability increases, in some cases dramatically, if the revenue is spent on either 1) Pull measures such as public transport alternatives (e.g. Ison, 2000 in a survey of UK stakeholders and Kottenhoff and Brundnell Freij, 2009 in their work on the Stockholm Congestion Charging scheme) or 2) To the direct benefit of car users, here revenue allocation to decrease transport taxes (road or fuel) is popular (e.g. Schuitema and Steg, 2008). The importance of mutually supportive packages of measures is also identified in Banister, (2008).

It is important that wider benefits are also identified (e.g. Banister, 2008). For fuels and technologies, Savvanidou et al (2010) find that those who view an increase in employment as a key advantage of growing biofuels are more likely to support biofuels over other renewable energy sources. While Thesen and Langhelle (2008) in the context of a hydrogen filling station in Greater Stavanger, Norway found that those in proximity to the station have higher support for the introduction of the hydrogen vehicles. Two, interesting, tentative reasons were suggested for this. First, that proximity results in a stronger sense of ownership and second, that technology is seen as progress and people want to live near progress.

This is also relevant for pricing mechanisms. For example health improvements through increased walking and cycling and reductions in car congestion could be highlighted as benefits associated with road pricing (Banister, 2008). De Groot and Steg, (2006) provide an interesting example of the level of impact that could be achieved in a study where they frame the costs of car use within a person's, more general well-being. The use of a range of indicators which included: environmental quality, safety, nature and biodiversity, meant that a doubling of car use resulted in only a minor decrease in overall quality of life. Where impacts are framed more broadly De Groot and Steg, (2006) suggest that the study respondents used a 'compensatory decision-making model' which enabled the offsetting of negative impacts with positive ones.

In identifying these benefits it is however important that they do not override the primary objective of the scheme, and that the primary objective remains clear and consistent. It is suggested (OECD/ITF, 2010) that too greater emphasis on environmental benefits may have been a factor in the rejection of congestion charging proposals in New York, though it is recognised that equity concerns were also key.

In summary, identifying and publicising wider benefits of the measure is necessary, though care is also required to make sure that the original objectives are not diminished. Where revenue is raised ensuring that it benefits those affected by the scheme can help play a key role in increasing acceptability. To ensure that consumers are aware of the benefits, further work is also likely to be required in certain areas, for example on fuel efficiency.

\section{The need for trust and alignment with values and norms}

The public needs to trust those implementing the scheme. For example, a lack of trust in the City of Edinburgh Council was identified as one of the reasons that the Edinburgh congestion charging scheme was not successful with bus users, who were expected to benefit from the public transport improvements (Gaunt et al, 2007). In the UK, road pricing can be viewed as a 'stealth tax on motorists (Bird and Morris, 2006) illustrating a lack of trust in government motives. For satellite road pricing systems, there are also (lesser) concerns about the availability of personal data, and invasion of privacy (Bird and Morris, 2006).

The need for trust is also relevant to the technology and fuel measures. For example people who trust research organisations for the management of biofuels introduction into the energy sector are more likely to pay extra for biofuels (Savvanidou et al, 2010). 
To gain and build this trust consistency with policy objectives and outcomes is required. Not doing so causes potential confusion and mistrust. For example the Fuel duty escalator was introduced in the UK in 1993, and abolished in 2000, after the fuel tax protests. Whilst robust environmental reasons were provided for the introduction and continuation of the escalator, there was no mention of these benefits during the protests. Instead, its contribution to the economy was highlighted. This was seen as weakening the environmental argument at a key point when it should have been a focus (Marsden, 2002).

People also need to trust that they are not acting in isolation (with limited benefit) and that changes in behaviour are in line with wider group values and norms. 'If driving is the norm and important others often drive their car, restrictions in car use are less acceptable' (Steg, 2003 providing Jakobsson et al, 2000 as an example). Steg (2003) also notes that people may be unwilling to reduce their personal car use if they do not trust that others will do the same. This ties in with the idea of a threshold of action which results in acceptability and is in line with the wider literature on the public acceptability of behaviour change (e.g. the 'I will if you will' report by the UK Sustainable Consumption roundtable, 2006). Here, examples of 'positive feedback' identified include Government's leading by example in terms of procurement and use of low carbon cars and councils providing street-level feedback on recycling and other sustainability achievements.

Individual, subjective factors are also identified as enabling (and acting as a barrier towards change) with Anable et al, (2006) providing a very useful review of these and collective (group) factors. Factors, at the individual level, include a sense of responsibility and moral norms, identity and status. Related to this, in the literature on public acceptability green motives and proenvironmental orientation were identified as playing a role in increasing the acceptability of measures (e.g. for travel demand management measures, Eriksson et al, 2008, and for new vehicle technologies, Gallagher and Muehlegger, 2008, O'Garra et al, 2007 on a study on hydrogen buses). Though it should also be noted that for new technologies Morton et al (2011) highlight that the wider literature on vehicle choice suggests that environmental benefits, in comparison with performance and upfront costs receive little consideration. In terms of affective attitudes the role of control is identified (Anable et al, 2006). Related to this, in the literature on public acceptability, Bird and Morris (2006) identified people fearing a loss of potential freedom as a key response to the introduction of road pricing. Though these fears, can of course, be overcome once the scheme is in place, and, where appropriate, alternatives in use.

In terms of fairness elements identified (Bird and Morris, 2006, and Steg, 2003 ${ }^{5}$ ) include is it unfair, at the personal, individual level because there are no viable alternatives - perceived or true? And is it unfair because it would disproportionately affect those on lower incomes. Perception of fairness and equity in relation to the cordon design are also important. In Edinburgh, 3 out of the 4 adjacent local authorities, opposed the introduction of the congestion charging scheme due to the apparent unfairness with regard to location and function of the cordons (Laird et al, 2007). Interestingly, Edinburgh residents who benefited most the scheme (and were the only ones entitled to vote at referendum) still voted no, for reasons explored in other sections of this paper. In relation to the Swedish congestion charge in order for Lidingö (an Island) residents to access the rest of Sweden they would have to go across the toll cordon twice. A compromise was reached whereby travel through the congestion charge area through or from Lidingö was exempt from the congestion charge. Though noted as an 'elegant solution' it had implications for costs of the scheme (Hamilton, 2010).

5. Note that Steg, 2003 is in reference to those on lower incomes 
The importance of fairness is apparent in other pricing mechanisms too. Bristow et al. (2010) examining public preferences for personal carbon trading (PCT) and a carbon tax highlight the importance of 'fairness'. For example for PCT, additional allowances for those with extra needs were preferred, while for carbon tax preferences included for the revenue to be used for threshold exemptions.

In summary, there is a need for trust in those introducing the scheme whether at the government, organisation or at the individual level; trust that others will also act accordingly, and that the scheme is fair. While this is not always easy to achieve, a number of mechanisms have been identified, these include the importance of:

- Consistent messages.

- $\quad$ Strong and clear political leadership.

- Transparent, accountable revenue spending.

- Revenue spending 'benefits' those impacted by the scheme.

- Data on the outcomes of the scheme from impartial sources.

- Information on the 'others who are doing their bit' is readily available, and widely publicized.

Individual, personal norms for example pro-environmental orientation can, potentially, help increase acceptability within certain groups, though this is clearly a key area where further research is required.

\section{Role of the media}

A number of the studies identify a role for the media in influencing public opinion and through inference the potential for acceptability (e.g. for road pricing generally Bird and Morris, 2006).

In the UK, potential charging schemes in Manchester and Edinburgh were unsuccessful at public referendum. In both cases media coverage of the scheme is identified as having an impact on public acceptability. Vigar et al. (2011) suggest, for Manchester (a Transport Innovation Fund bid which included significant investment in public transport) that many aspects of the scheme were not explained fully in the media; in terms of the framing of the articles the emphasis was on congestion charging rather than the public transport aspects - that the scheme would operate as a package of measures was not clear. Ryley and Gjersoe, (2006) which considered the Edinburgh scheme, identified that the newspaper coverage was highly politicised and increasingly negative as Edinburgh moved towards the public referendum.

It is also important to note that media opinion can over change over time and have a positive role. With the Stockholm congestion charging scheme, in the opinion lead articles, with the pretrial articles there were no positive articles at all, $89 \%$ were negative and $11 \%$ were neutral. During the trial the emphasis in the articles changed, with $25 \%$ positive, $63 \%$ negative and $12 \%$ neutral. (Winslott- Hiselius et al, 2009). In terms of a positive role, in the Greater Stavanger hydrogen study (Thesen and Langhelle, 2008) the media interest focused on affirmative features - environmental aspects, technological development and benefits to the region. Banister (2008) also identifies the role that the media can play in (positive) promotion of new schemes. 
Whether the public have a role in influencing the media, is also an interesting question. Ryley and Gjersoe (2006) identify that letters to newspapers were used to report opinion on the proposals, but conclude by suggesting that there was more emphasis on an opinion making than a reporting role.

In terms of ensuring that the most positive engagement with the media can occur the following actions are identified. First, there needs to be on-going engagement with media professionals (Vigar et al, 2011). Second, this engagement needs to include information on the outcomes of the scheme. Eliasson (2008) suggests that the media need to be supplied with key data on the reduction of traffic volumes and congestion levels, and that the data needs to be impartial with data coming from independent researchers and experts.

In summary, the media is identified as playing an important role in 'framing the debate' and influencing public opinion. Steps to help overcome this include:

- On-going engagement with media professionals.

- Ready availability of data from impartial sources.

- Strong political champion to 'ride out' negative coverage, if necessary.

\section{CONCLUSIONS AND RECOMMENDATIONS}

Political efforts towards the sustainability of the transport sector are in place (e.g. EC, 2011). This is in the context of recent unsustainable trends, as they relate to increased demand for mobility (EEA, 2009). Public acceptability plays a central role in addressing this unsustainability and ensuring effective sustainable measures (e.g. Windsperger et al, 2008; Van den Bergh et al, 2007; Brohomann et al, 2008). This paper has identified the difficulties faced in achieving acceptability of sustainable transport measures but also identifies a number of positive ways forward. The following tentative conclusions and recommendations are drawn.

First, is that, interestingly, a number of the messages found in the study can be applied 'across the board' i.e. they are applicable to pricing measures, alternatives to car based transport and the introduction of new technologies and fuels. So for example, the importance of trust can be seen to be applicable to pricing measures and the shift to public transport - will other people 'do their bit'? As well as to technological measures - can I trust, through observing others behaviour, that new vehicle technologies and fuels are working well.

Second, is the importance of clear, understandable, information on how the schemes will operate (fairly and equitably); associated benefits and how the revenue is spent. For example, that the London Congestion Charge scheme was easy to understand was integral to its success. Engaging and involving the public at the scheme design stage can assist in ensuring this understanding. Where benefits are not currently easily understood by the public, for example with regards to fuel efficiency, innovative methods to address this are required. For example, fuel cost information could be provided on a per model basis (Anable, 2008).

Third, the importance of real-life examples is also recognised, people need to see schemes and technologies 'in action' to address concerns and fears. These real-life examples can include: for road pricing - trial schemes, for new vehicle technologies - widespread demonstration schemes. The take up of new vehicle technologies may also benefit from a 'neighbourhood 
effect' whereby market penetration increases consumer confidence (e.g. Mau et al, 2008 and Axsen et al, 2009). This is an area which requires further research since it may be appropriate for new vehicle technologies and fuels to be strategically positioned to help ensure understanding, acceptability and take up by the market.

Fourth, is the need for further research in a number of areas. This includes research on 1) the acceptability of new technologies and fuels. While these are explored in the literature, given the extent of forecast technological change (and the necessary public take up of these new technologies) further work in this area is required. As described above the role of neighbourhood effects in ensuring acceptance of these new technologies is a potential key area for additional research. 2) The modes where forecast growth is greatest. For example aviation where modal shift to rail and use of biofuels to fuel planes are identified as carbon reduction policies. Understanding barriers to acceptability of these measures is important. For example, for modal shift to rail, its potential high cost, difficulties with booking (multi-country) travel, and the time it can, currently, take may affect acceptability. 3) Data and analysis at the individual level (rather than aggregate) to understand changes in public attitudes to transport measures over time is also essential and highly relevant to policy development (Goodwin and Lyons, 2010).

Fifth, is the role of the media. It should, ideally, play a positive role in the framing of pricing schemes, alternatives to car-based transport and new technology and fuel options. Engagement with the media can help here, particularly in the run up to pricing scheme implementation where research suggests public acceptability declines. Data on the outcomes of the schemes from impartial sources is also important in gaining media, and wider support. Where the media is difficult to engage with strong political leadership and consistency in messages is essential to overcome any negative coverage.

Finally, in implementing measures to bring about behaviour change flexibility is often necessary. This is to ensure that the level of public acceptability is increased to the extent that it becomes and remains politically acceptable. The impact that this can have on the effectiveness of the scheme is, however, recognised (e.g. Banister, 2008, Richardson, 2011 and OECD/ITF, 2010) and is linked to the concepts of weak and strong visions for sustainability (Himanen et al, 2005, Miola, 2007). 


\section{REFERENCES}

Anable J., Lane B., and Kelay T. (2006) An Evidence Base Review of Public Attitudes to Climate Change and Transport Behaviour. A report to the UK Department for Transport. http://www.dft.gov.uk/pgr/sustainable/reviewtransportbehaviourclimatechange/pdf/iewofpub licattitudestocl5730.pdf

Anable J., Lane B., and Banks N (2008) Car buyer survey: From 'mpg paradox' to 'mpg mirage' How car purchasers are missing a trick when choosing new and used cars. Report to the Low Carbon Vehicle Partnership. http://www.lowcvp.org.uk/assets/reports/Car Buyer Report 2008 Final Report.pdf

Atanasiu B (2010) The role of bioenergy in the National Renewable Energy Action Plans: a first identification of issues and uncertainties. Institute for European Environmental Policy. http://www.ieep.eu/assets/753/bioenergy in NREAPs.pdf

Axsen J., Mountain D.C., Jaccard M., (2009) Combining stated and revealed choice research to simulate the neighbor effect: The case of hybrid-electric vehicles. Resource and Energy Economics Volume 31, Issue 3, August 2009, Pages 221-238.

Banister D (2008) The sustainable mobility paradigm. Transport Policy 15 (2008) 73-80.

Bird J. and Morris J. (2006) Steering Through Change - Winning the Debate on Road Pricing. Institute for Public Policy Research.

Bristow A.L. Wardman M., Zanni A.M., Chintakayala P.K. (2010) Public acceptability of personal carbon trading and carbon tax. Ecological Economics 69 (2010) 1824-1837.

Brohmann B, Barth R, Eberle U, Heiskanen E., Schimitt K, Wolff F. (2008) Policies to promote sustainable consumption pattern". Proceeding of $2^{\text {nd }}$ Conference of the Sustainable Consumption research Exchange (SCORE) February, 2008. www.score-network.org

De Groot and Steg (2006) Impact of transport pricing on quality of life, acceptability, and intentions to reduce car use: An exploratory study in five European countries. Journal of Transport Geography 14 (2006) 463-470.

Eliasson J. (2008) Lessons from the Stockholm Congestion Charging Trial. Transport Policy 15 (2008) 395-404.

Eliasson J. (2010) So you're considering congestion charging? Here's what you need to know. FAQ based on Stockholm's experiences. In OECD/ITF (2010) Implementing Congestion Charging, Roundtable 147.

Eriksson L., Garvill J., Nordlund A.M (2008) Acceptability of single and combined transport policy measures. The importance of environmental and policy specific beliefs. Transportation Research Part A 42 1117-1128.

European Commission (2011) “WHITE PAPER- Roadmap to a Single European Transport Area - Towards a competitive and resource efficient transport system”. COM(2011) 144 final Brussels, 28.3.2011. 
European Environment Agency (2009) "Towards a resource-efficient transport system, TERM 2009: indicators tracking transport and environment in the European Union. ISBN 978-929213-093-0.

Farrington, J., H., (2007), The new narrative of accessibility: its potential contribution to discourses in (transport) geography. Journal of Transport Geography. Volume 15, Issue 5, Pages 319-330.

Gallagher K. and Muehlegger E. (2008) "Giving Green to Get Green? Incentives and Consumer Adoption of Hybrid Vehicle Technology." Working Paper, Harvard Kennedy School (January 2008).

Garling T and Schuitema G (2007) Travel Demand Management Targeting Reduced Private Car Use: Effectiveness, Public Acceptability and Political Feasibility. Journal of Social Issues, Vol. 63, No. 1, 2007, pp. 139-153.

Gaunt M., Rye. T and Allen S. (2007) Public Acceptability of Road User Charging: The Case of Edinburgh and the 2005 Referendum. Transport Reviews Vol. 27, No 1, 85-102, January 2007.

Gehlert T., Kramer C. Nielsen O. A. Schlag B. (2011) Socioeconomic differences in public acceptability and car use adaptation towards urban road pricing. Transport Policy doi:10.1016/j.tranpol.2011.01.003.

Goodwin P. (2006) "The gestation process for road pricing schemes", Local Transport Today, 1 June vol 444: 17.

Goodwin, P. and Lyons, G. (2010). Public attitudes to transport: interpreting the evidence. Journal of Transportation Planning and Technology: UTSG special issue, 33(1), 3-17.

Hamilton C (2010) Revisiting the cost of the Stockholm Congestion Charging System. OECD/ITF (2010) Implementing Congestion Charging, Roundtable 147.

Heffner R.R., Kurani K.S, Turrentine T.S (2007) Symbolism in California's early market for hybrid electric vehicles. Transportation Research Part D 12 (2007) 396-413.

Heutel G. and Muehlegger E (2010) Consumer Learning and Hybrid Vehicle Adoption. Harvard Kennedy School. Faculty Research Working Paper series.

Himanen,V., Lee-Gosselin, M., Perrels, A. (2005), Sustainability and the interactions between external effects of transport. Journal of Transport Geography 13(2005) 23-28.

Ison S. (2000) Local authority and academic attitudes to urban road pricing: a UK perspective. Transport Policy 7 (2000) 269-277.

Jakobsson C., Fujii S., and Garling T (2000) Determinants of private car users' acceptance of road pricing. Transport Policy 7, 153-158.

Kottenhoff, K, Brundell Freij, K., (2009). The role of public transport for feasibility and acceptability of congestion charging - The case of Stockholm. Transportation Research Part A: Policy and Practice, Volume 43, Issue 3, pp 297-305. 
Laird J., Nash C., Shepherd S. Chapter 8 Cordon charges and the use of revenue: A case study of Edinburgh. Research in Transportation Economics. Volume 19, 2007, Pages 161-187, Investment and the Use of Tax and Toll Revenues in the Transport Sector.

Larsen O.I (1995) The toll cordons in Norway: an overview. Journal of Transport Geography Vol 3. No 3. pp 187-197.

Marsden G., (2002) Fuel Taxes and the Environment-Economy Trade Off. In Lyons G and Chatterjee K. (2002) Transport Lessons from the Fuel Tax Protests of 2000. Ashgate.

Mau P., Eyzaguirre J., Jaccarda M., Collins-Dodd C., Tiedemann K., (2008) The 'neighbor effect': Simulating dynamics in consumer preferences for new vehicle technologies. Ecological Economics 68 (2008) 504-516.

Miola, A., Ciuffo, B., Marra, M., Giovine, E., (2010). Regulating air emissions from ships: the state of the art on methodologies, technologies and policy options. JRC Reference Report. EUR - Scientific and 11 Technical Research series -ISBN 978-92-79-17733-0. Luxembourg.

Miola A., (2008) Backcasting approach for sustainable mobility EUR - Scientific and Technical Research series - ISSN 1018-5593 - ISBN 978-92-79-09189-6 Luxembourg: Office for Official Publications of the European Communities Luxembourg.

Miola A., (2007) Transport and sustainability: a review. EUR - Scientific and Technical Research series ISSN 1018-5593 - ISBN 978-92-79-06933-8, Luxembourg.

Morton C., Schuitema G., and Anable J. (2011) Electric Vehicles: Will Consumers Get Charged Up? Universities's Transport Study Group Conference January 2011, Open University, Milton Keynes.

Musselwhite C.B.A and Lyons G (2009). Exploring the public acceptability of road pricing. Proceedings of the $41^{\text {st }}$ Universities Transport Study Group Conference, University College London, January 2009.

Oehry B (2010) Critical Success Factors for Implementing Road Charging Systems. Discussion Paper 3. Joint Transport Research Centre Round Table 4-5 February, 2010. Paris. International Transport Forum OECD.

O'Garra T., Mourato S. and Pearson P., (2005) Analysing awareness and acceptability of hydrogen vehicles: A London case study. International Journal of Hydrogen Energy 30 (2005) 649-659.

O'Garra T., Mourato S., Garrity L., Schmidt P., Beerenwinkel A., Altmann M., Hart D., Graesel C., Whitehouse S., (2007) Is the willing to pay for hydrogen buses? A comparative study of preferences in four cities? Energy Policy 35 (2007) 3630-3642.

Organization for Economic Co-operation and Development - OECD and International Transport Forum (2010) Round Table 147 Implementing Congestion Charges.

Organization for Economic Co-operation and Development - OECD (2000) Environmentally Sustainable Transport: futures, strategies and best practices. Synthesis Report of the OECD Project on Environmentally Sustainable Transport (EST) - International EST Conference $4^{\text {th }}$ to $6^{\text {th }}$ October 2000, Vienna, Austria. 
Panaytou, T. (1992) Economics of Environmental Degradation. The Earthscan Reader in Environmental Economics. Markandya, A., and Richardson, J. Earthscan. London.

Richardson, T., Isaakson, K., Gullberg, A., 2010. Changing frames of mobility through radical policy interventions? The Stockholm congestion tax. International Planning Studies 15 (1), pp53-67.

Rogers E.M. (2003) Diffusion of innovations (5th ed.). New York: Free Press.

Ryley T., Davison L., Bristow A. and Pridmore A., (2009) Public Engagement on Aviation Taxes in the United Kingdom. International Journal of Sustainable Transportation, 4(2), 2010, pp 112-118.

Ryley T. amd Gjersoe N., (2006) Newspaper response to the Edinburgh congestion charging proposals. Transport Policy 13 (2006) 66-73.

Savvanidou E., Zervas E., Tsagarakis K.P., (2010) Public acceptance of biofuels. Energy Policy 38 (2010) 3482-3488.

Schade J., and Schlag B. (2000) Acceptability of Urban Transport Pricing. VATT research reports. http://www.vatt.fi/file/vatt publication pdf/t72.pdf

Schade J., and Schlag B. (2003) Acceptability of urban transport pricing strategies, Transportation Research Part F 45-61.

Schuitema G. and Steg L. (2008) The role of revenue use in the acceptability of transport pricing policies. Transportation Research Part F 11 (2008) 221-231.

Schuitema G., Steg L. and Rothengetter J.A. (2010) The acceptability, personal outcome expectations, and expected effects of transport pricing policies. Journal of Environmental Psychology 30 (2010) 587-593.

Steg, L. (2003). Factors influencing the acceptability and effectiveness of transport pricing. In: J. Schade \& B. Schlag (Eds.), Acceptability of transport pricing strategies, pp. 187-202. Amsterdam: Elsevier.

Sustainable Consumption Roundtable (2006) I will if you will - towards sustainable consumption. http://www.sd-commission.org.uk/publications/downloads/l Will If You Will.pdf

Thesen G. and Langhelle O. (2008) Awareness, acceptability and attitudes towards hydrogen vehicles and filling stations: A Greater Stavanger case study and comparisons with London. International Journal of Hydrogen Energy 33 (2008) 5859-5867.

Transport for London (2004), Congestion Charging Central London. Impacts Monitoring Second Annual Report.

Tretvik T. (2003) Urban road pricing in Norway: Public acceptability and travel behaviour. In Schade J. and Schlag B. eds (2003) Acceptability of Transport Pricing Strategies.

United Nations (2001) Sustainable Transport Pricing and Charges - Principles and Issues. Economic and Social Commission for Asia and the Pacific/ Asian Institute of Transport Development. 
Vägverket (2002) 'Road pricing in urban areas', Vägverket, available at: www.transportpricing.net/download/swedishreport.pdf

Van Den Bergh J.C.J.M., Van Leeuwen E. S. Oosterhuis F.H., Rietveld P., Verhoef E.T. (2007) Social learning by doing in sustainable transport innovations: Ex-post analysis of common factors behind success and failures. Research policy 36 (2007) 247-259.

Vigar G., Shaw A., Swann R., (2011) Selling sustainable mobility: The reporting of the Manchester Transport Innovation Fund bid in UK media. Transport Policy 18 (2011) 468-479.

Windsperger A., Christian R., Schenider P. (2008) Structural and mental obstacles for effective mitigation of climate change" Proceeding of $2^{\text {nd }}$ Conference of the Sustainable Consumption research Exchange (SCORE) February, 2008. www.score-network.org

Winslott-Hiselius L., Brundell-Freij K., Vagland A., Byström C., (2009) The development of public attitudes towards the Stockholm congestion trial. Transportation Research Part A 43 (2009) 269-282.

Yetano Roche M., Mourato S., Fischedick M., Pietzner K., Viebahn P., (2010) Public attitudes towards and demand for hydrogen and fuel cell vehicles: A review of the evidence and methodological implications. Energy Policy 38 (2010) 5301-5310. 
E International

International Transport Forum

2 rue André Pascal

75775 Paris Cedex 16

itf.contact@oecd.org

www.internationaltransportforum.org 